\title{
Braunschweig: A Historiography of Ordinary Germans and the Holocaust
}

\author{
Katelyn McGirr
}

Echoing a joke that made the rounds in Berlin in 1941, German resistance fighter Edith Wolff remarked that "Germany is now called Braunschweig: one half is brown [Braun = Nazi uniforms] and the other half is silent [schweig = silence]."1 This paper aims to create a dialogue between major authors and their published works through a comparative analysis of the political, social, cultural, and economic aspects of 'ordinary' - or civilian - Germans before, during, and after WWII and the Holocaust. Reviewed through the theoretical lens of the Intentionalist and Functionalist perspectives, this essay will discuss the ordinary German's reactions to the National Socialist regime, the prevalence of German anti-Semitism, the legitimacy of collective responsibility and collective guilt, and how memory and historical approaches to the discourses of the Holocaust influenced German collective identity. This essay will demonstrate the need for the integration of Intentionalist and the Functionalist theory to accurately reconstruct the contextual framework of the Holocaust. We will begin our discussion with the origins of this historiographical debate, and a summary of the Intentionalist, Functionalist, and Synthesis theoretical philosophies.

The historiographical debate on the origins of the Holocaust as well as most aspects of the Third Reich centres around two questions: was it Adolf Hitler's master plan to launch the Holocaust? And, did the initiative to execute the Holocaust come from above with orders from the Fuhrer or from below within the German bureaucracy? In an effort to answer these questions,

\footnotetext{
${ }^{1}$ Marion A. Kaplan, “When the Ordinary Became Extraordinary: German Jews Reacting to Nazi Persecution, 19331939, " in Social Outsiders in Nazi Germany, edited by Robert Gellately and Nathan Stoltzfus (New Jersey:

Princeton University Press, 2001), 74.
} 
two distinct groups of historians emerged: the 'Intentionalists' and the 'Functionalists'. Intentionalists believe that Hitler had plans for the Holocaust well before the Nazi regime came into power in 1933, and often cite his anti-Semitic statements from as early as 1919 as evidence. They believe that Hitler, as the Fuhrer, was personally responsible for encouraging national antiSemitism, and that the initiative to kill the entire Jewish people came from him and his prominent Nazi members. $^{2}$

The majority of the historians in this field, however, reject the oversimplified reasoning of the Intentionalists in favour of the Functionalist perspective. Functionalists claim that the Nazi leadership had little to do with initiating the Holocaust, and instead incriminate the lower ranks of the German bureaucracy. Also referred to as the 'bottom-up approach,' Functionalists believe that it was the rivalry within the unstable Nazi social structure that motivated the Holocaust. Hitler, they believe, shied away from decision-making on key issues; instead leaving it to subordinates from different agencies to fight it out, with the winner awarded Hitler's approval to act on their ideas. ${ }^{3}$ A variance on the Functionalist interpretation is that it was only after failing to expel all of the Jews from Europe that the Nazis resorted to genocide.

Regardless of conflicting premises, both the Functionalists and Intentionalists substantiate the already established belief that those who executed the 'Final Solution' had little personal interest in what they were doing. The distinction becomes apparent in how each group categorizes the people involved. Intentionalists view those involved in the Holocaust as Hitler's unwilling henchmen under the wrath of their supervisors. Adversely, Functionalists regard them as unaware, anonymous cogs within a larger machine being driven by other forces. ${ }^{4}$ It was not

\footnotetext{
${ }^{2}$ Jürgen Matthäus, "Historiography and the Perpetrators of the Holocaust" in The Historiography of the Holocaust, edited by Dan Stone (New York: Palgrave Macmillan, 2004), 204.

${ }^{3}$ Ibid.

${ }^{4}$ Ibid., 205.
} 
until the 1990s that scholarship moved away from the dualism of Intentionalist and Functionalist thought to less systematic theory. A number of scholars, including Ian Kershaw and Michael Marrus, developed a theory that integrated the Functionalist and Intentionalist schools; for our purposes, this theory will be referred to as the "Synthesis Perspective."

They suggest that the Holocaust was the result of pressures from above and below, and that Hitler lacked a master plan, but was a decisive force behind the Holocaust. To sum up the way extreme rhetoric and competition among different Nazi agencies produced extreme policies, the term "cumulative radicalisation" is used. Cumulative radicalism, the Synthesis Perspective argues, is the result of fanatical bureaucratic underlings putting into practice what they believed Hitler would have approved of based on his widely publicized speeches and propaganda. To some extent, all the historians discussed in this essay, including Goldhaggen, Meinecke, Arendt, Hilberg, Browning, Kühne, and Peukert exhibit both the Intentionalist and Functionalist perspectives.

Detlev J.K. Peukert's Inside Nazi Germany subscribes to the 'Seduction or Supervision' theory of the Functionalist perspective. Seduction theory emphasizes the active, or at best passive, consent that the majority of the German population gave to the National Socialist regime. ${ }^{5}$ Supervision theory argues that the system of control, internal policing, and espionage in the Third Reich were so efficient that the slightest opposition would likely lead a person to the concentration camp. ${ }^{6}$ While Peukert does not clearly choose one theory or the other in his book, other historians would argue that both the National Socialists' rise to power and the continued support they received during the war are more complicated situations than a case of propaganda versus fear. Peter Fritzsche suggests that the dire economic circumstances at the end of the

${ }^{5}$ Detlev J.K. Peukert, Inside Nazi Germany, trans. Richard Deveson (London: Tameside Filmsetting Ltd, 1987$), 67$. 6 Ibid. 
Weimar Republic, along with the humiliation of military defeat in WWI, made Germans more receptive to the idea of converting to a new set of ideas, and were more willing to accept the use of violence to acquire them. ${ }^{7}$ In contrast to the depression of 1932, there was an 'economic miracle' in Germany that would continue from 1936 onward. The fact that this economic boom was based on inflation and dependent on the production of military weapons was thought, by Peukert, to be ignored by the German population. ${ }^{8}$

This discrepancy between the actual achievements of the Third Reich and the images propagated to the public, Peukert argues, is the by-product of the Fuhrer myth. A concept of the Intentionalists, the Fuhrer myth bridges the gap between security and a positive outlook on the future, and disenchantment with everyday Third Reich life. ${ }^{9}$ National Socialist ritual and mass events, particularly with the appearance of Adolf Hitler, enabled followers to feel a sense of belonging and reassurance of their own significance. Associated with the regime's achievements, National Socialists were careful to separate Hitler from criticism. So much so, that "If the Fuhrer knew about this..." was a standard phrase in Germany society. ${ }^{10}$ This separation from criticism and longing for normality from the German population, which had been shaken by crisis and whose social point of reference had been thrown into disarray, is what Intentionalist historians believe to have been the appeal of the Fuhrer myth. Even non-monarchist and non-militaristic Germans favoured the National Socialist regime over the political confusion and personal insecurity of the Weimar period.

From a psychological approach, Fritzsche also applies this idea to the regime's foreign policy. Promoting an ideal German life, Nazis linked the near-death they believe Germany had

\footnotetext{
${ }^{7}$ Peter Fritzsche, Life and Death in the Third Reich (Cambridge: Caravan Books, 2008), 8.

${ }^{8}$ Peukert, Inside Nazi Germany, 71.

${ }^{9}$ Ibid., 72.

${ }^{10}$ Ibid.
} 
suffered in 1918 to the need to ruin other nations and sentence people to death. ${ }^{11}$ The misfortunes of individual Germans in the Weimar years were effectively portrayed by National Socialists as the misfortunes of the nation, convincing the populace that they had both internal and external enemies. ${ }^{12}$ Intentionalists argue that this manipulation of the Germans' psyche was part of Hitler's predetermined master plan to gain consent for the elimination of Europe's Jewish population.

Conversely, Fritzsche, as a Functionalist, does not regard Hitler as a central figure in German life. Based on the diaries referenced in his book, Life and Death in the Third Reich, Fritzsche argues that it was consent offered at the local level that the National Socialist regime needed most. ${ }^{13}$ Fear, opportunism, careerism, and a varying degree of ideological conviction, Fritzsche suggests, were the elements needed for basic consent to the regime, and were necessary to ensure that the system would function on a day-to-day basis. ${ }^{14}$ Peukert questions whether active consent and sympathy with the goals and actions of the regime are enough to explain why National Socialism remained politically unchallenged within Germany. ${ }^{15}$ Passive consent, he argues, rests on a process both fostered and combatted by the Nazi regime, which is retreating to the private sphere. With opposing political views now criminalized under National Socialism, a large section of the population began to lead a 'double life'. ${ }^{16}$ In public, people pledged their loyalty and met their quotas of economic output, but in private, many pursued non-political leisure activities that created minimal interference from local Nazi bureaucrats. ${ }^{17}$ Aptly described by Peukert, life under the National Socialist regime was "[ . . ] a state of subservience sweetened

\footnotetext{
${ }^{11}$ Fritzsche, Life and Death in the Third Reich, 5.

${ }^{12}$ Ibid., 16.

${ }^{13}$ Ibid., 11.

${ }^{14}$ Ibid., 73.

${ }^{15}$ Peukert, Inside Nazi Germany, 77.

${ }^{16}$ Ibid., 73.

${ }^{17}$ Ibid., 79 .
} 
by privileges." 18

These privileges were most evident in the differing treatment of Jewish and non-Jewish Germans by Nazi authorities. Based on the information gathered from surveys completed by Jewish survivors of WWII, Eric A. Johnson and Karl-Heinz Reuband are confident in their findings on the anti-Semitic atmosphere of Nazi Germany. They suggest that before 1933, most Jews enjoyed what they described as 'cordial relations' between themselves and the non-Jews in their community. ${ }^{19}$ Jews that stayed in Germany longer during the war, were more likely to have their homes and businesses vandalized, to have been spied on by their German neighbours, coworkers, and fellow classmates, and suffered verbal taunts and threats from German civilians. ${ }^{20}$ Johnson and Reuband's evidence indicates that anti-Semitism, before Hitler came to power, was either dormant or had not been widespread among the German population. ${ }^{21}$ This supports the Functionalists' theory that the unstable National Socialist social structure is what motivated the Holocaust.

In his book, Hitler's Willing Executioners, Daniel Jonah Goldhagen discounts Johnson and Reuband's collected primary data. He argues that there is no evidence to support the notion that the intense and all present public anti-Semitism was the same as people's private beliefs. ${ }^{22}$ While discussing truisms perpetuated by other historians in his first chapter, Goldhagen denounces the theory that Nazi anti-Semitism was integral to the beliefs of ordinary Germans. He writes: "[ $[.$.$] evidence exists that anti-Semitism, albeit an anti-Semitism evolving in content$ with the changing times, continued to be an axiom of German culture throughout the nineteenth

\footnotetext{
18 Peukert, Inside Nazi Germany, 73.

${ }^{19}$ Eric A. Johnson and Karl-Heinz Reuband, What We Knew: Terror, Mass Murder, and Everyday Life in Nazi Germany (Cambridge: Basic Books, 2005), 389.

${ }^{20}$ Ibid., 390.

${ }^{21}$ Johnson and Reuband, What We Knew, 389.

${ }^{22}$ Daniel Jonah Goldhagen, Hitler's Willing Executioners (New York: Alfred A. Knope, Inc., 1996), 30.
} 
and twentieth centuries, and that its regnant version in Germany during its Nazi period was but a more accentuated, intensified, and elaborated form of an already broadly accepted basic model." ${ }^{23}$ Goldhagen criticizes historians that fail to specify and analytically separate German anti-Semitic dimensions, arguing there are three: the source of the Jews' malefic qualities, the latent manifest (described as how preoccupied an anti-Semite is with Jews), and the level or intensity of the anti-Semitism as a continuum representing the putative perniciousness of the Jew. $^{24}$ Due to these varying dimensions, some anti-Semitic beliefs become woven into the moral order of society, while others do not.

One example of anti-Semitic beliefs that permeated German society was Jewish economic exclusion. Due to what Functionalist Frank Bajohr describes as 'conspiratorial notions' Nazis had towards Jews, the new regime had an immediate effect on the economic well-being of German Jews in $1933 .^{25}$ Previous business partners of Jewish owned companies, either voluntarily or under pressure from National Socialist bureaucrats, dropped their contracts, and many Jews were forced to close or sell their businesses. ${ }^{26}$ Competitors took advantage of the situation to expand their shares in the market through numerous and often violent boycotts, and anti-Semitic propaganda to denounce their Jewish counterparts. ${ }^{27}$ By 1938 , the legally enforced "Aryanization" of Jewish businesses brought a swift end to any remaining Jewish enterprises in Germany. Before the war, German society determined the social ranking of an individual through his possessions, education, and degree of success. With the National Socialists' focus on the "racial status" of the individual, the bourgeois code of values had little validity, especially when

\footnotetext{
${ }^{23}$ Goldhagen, Hitler's Willing Executioners, 31.

${ }^{24}$ Ibid., 35.

${ }^{25}$ Frank Bajohr, "No "Volksgenossen": Jewish Entrepeneurs in the Third Reich," in Social Outsiders in Nazi Germany, edited by Robert Gellately and Nathan Stoltzfus (New Jersey: Princeton University Press, 2001 ), 45.

${ }^{26}$ Ibid.

${ }^{27}$ Ibid., 49.
} 
applied to Jewish entrepreneurs. ${ }^{28}$ Parallel to Bajohr, Goldhagen argues that Jews are not simply evaluated according to a culture's moral principles and norms, but become constitutive of the moral order itself. By defining Jews as opposing the fundamental good towards which people ought to strive, linguistic, metaphoric, and symbolic integration of Jews into the anti-Semites' lives increases the latent manifest of anti-Semitism. ${ }^{29}$ Regardless of the discrepancies in the definition of anti-Semitism, few scholars accept the exaggerated claim that most Germans shared the "exterminatory" anti-Semitic sentiment with Nazi leaders. ${ }^{30}$

If most Germans did not share the same exterminatory sentiments of their Nazi leaders, then to what extent does Thomas Kühne's statement "[ . . . the murder of the Jews was a German crime, not only a Nazi crime" apply to the collective responsibility of 'ordinary' Germans? ${ }^{31}$ Following the end of the war, the Nuremberg Trials held only the top-ranking Nazis responsible for the crimes committed, and they were convicted on the basis of individual guilt. Transferring the responsibility to a limited number of individuals allowed Germans to escape into a discourse of victimization. As a result, the Einsatzgruppen (SS) "[. . .] quickly became what Gerald Reitlinger called the 'alibi of a nation'." ${ }^{32}$ Most Germans, as individuals, insisted on not having done anything wrong, including not personally committing murder. In what Kühne describes as a coping mechanism, Germans believed there was nothing they could do; seduced by Hitler and terrorized by the Gestapo, they were at the mercy of a

military machine with their own injuries to heal from. In this Intentionalist view, Nazis resemble the morally weak predators pursuing war and conquest while ordinary citizens worried about

\footnotetext{
${ }^{28}$ Bajohr, "No "Volksgenossen," 47.

${ }^{29}$ Goldhagen, Hitler's Willing Executioners, 38.

${ }^{30}$ Fritzsche, Life and Death in the Third Reich, 7.

${ }^{31}$ Thomas Kühne, Belonging and Genocide (New Haven: Yale University Press, 2010), 163.

${ }^{32}$ Matthäus, "Historiography and the Perpetrators of the Holocaust," 199.
} 
their own lives. ${ }^{33}$

Functionalist historian Jürgen Matthäus, argues however that the "socialization towards mass murder involves conscious decisions at every stage." 34 Through unavoidable participation on a daily basis, Germans in a variety of roles and in different degrees of commitment were complicit in mass crime just as small cogs in a large machine. ${ }^{35}$ Instilling inclusion through the exclusion of others, National Socialism replaced the Judeo-Christian tradition of universal humanity and individual responsibility with a morality that revolved around the needs of the "Us." ${ }^{\prime 36}$ Kühne and Benedict Anderson point to the camaraderie that Germans felt through harassing, boycotting, and isolating Jews, other non-Aryans, and any other enemies deemed "alien" to the community. Encouraged by the Nazi regime after 1933, Germans were seen as weak and lacking community spirit if they displayed pity or compassion for "Them." Many Germans avoided contact or severed relations with Jewish neighbours, friends, and colleagues, but only a minority participated willingly in collectively violent anti-Semitism. ${ }^{37}$ Despite these considerations, little attention has been given to individual responsibility, motives and interests, which is why Functionalists are often criticized for depersonalizing the Holocaust and for overemphasizing the 'banality of evil'. ${ }^{38}$

The Synthesis perspective argues that in addition to the empirical evidence of collective responsibility, there is also political motivation to refuse the claims of German victimhood. Despite the lives, loved ones, and homes lost in consequence of the Allied air raids and the Russian invasion, perceiving themselves as victims allowed Germans to admit only collective

\footnotetext{
${ }^{33}$ Fritzsche, Life and Death in the Third Reich, 6.

${ }^{34}$ Matthäus, "Historiography and the Perpetrators of the Holocaust," 210.

35 Peukert, Inside Nazi Germany, 73.

${ }^{36}$ Kühne, Belonging and Genocide, 164.

${ }^{37}$ Ibid., 167.

${ }^{38}$ Matthäus, "Historiography and the Perpetrators of the Holocaust," 205.
} 
responsibility and not collective guilt. ${ }^{39}$ Dagmar Barnouw reasons that claims of German victimization are feared by U.S. administration and Israel because it undermines the familiar scenario of Good versus Evil that was established by the Allies as victors in the 'just' WWII. ${ }^{40}$ Barnouw expands his theory of feared German victimization to include Jewish-German intellectuals, who insist on a permanent uniqueness of Jewish suffering that is beyond all human understanding. It is his impression that the Holocaust has become a Zivilreligion, in which the correct way to deal with memory stories of Holocaust survivors is absolute empathy and unquestioning recording as acts of religious devotion. ${ }^{41}$ The powerful cultural status of the Holocaust as a religious, supra-historical allegory of victimization, Barnouw argues, makes the search for historical evidence largely irrelevant. ${ }^{42}$

The expectations of a permanent sameness of German guilt and remorse are, like the supra-historical Jewish victim status, also too rigidly defined. The news of the mass murder of Jews, and war crimes on the Eastern Front during WWII instigated stereotypes of barbarian and power-obsessed German national character that had culminated in Nazi Germany's anti-Semitic and master race ideology. ${ }^{43}$ Memories of German guilt were to become the public memory discourses of WWII while memories of German loss were to be excluded from the public remembrance, as well as from historical memory. ${ }^{44}$ For the first six decades after the war, the general instability of memories of German losses were hardly seen as an issue since Germans were collectively encouraged to focus less on their personal war experiences, and instead concentrate on the experiences of their regime and their victims. ${ }^{45}$ This follows the long-standing

\footnotetext{
${ }^{39}$ Kühne, Belonging and Genocide, 163.

${ }^{40}$ Dagmar Barnouw, The War in the Empty Air (Bloomington: Indiana University Press, 2005), 65.

${ }^{41}$ Ibid., 66.

${ }^{42} \mathrm{Ibid}$.

${ }^{43}$ Kühne, Belonging and Genocide, 162.

${ }^{44}$ Barnouw, The War in the Empty Air, 52.

${ }^{45}$ Ibid., 54.
} 
argument made at the end of the war, that memories of German war loss would diminish the memories of their regime's victims, and alleviate some weight of German guilt with the assertion "we suffered too." 46 Younger generations of Germans found it difficult to deal with the complexities and contradictions of their parents' past, and this was reason enough to avoid these "forbidden topics." ${ }^{\prime 7}$ Dubbed by Barnouw as the 'children's generation', their individual view of Germany's past was that it was as bad as it was abstract. Although Germans are aware of how immensely they and their country had violated the basic values of their civilization, many insist that their ancestors could not be Nazis. Goldhagen believes it is this denial that cultivated the nation's struggle for a collective identity after unification. This enduringly narrow post-Holocaust perspective on German guilt and fixation on German remorse, though understandable to Barnouw in the first decades following the war, has led to a build-up and increased cultural centrality of the Holocaust.

Barnouw predicts that memory of Nazi criminality will last for a time, but not forever. Moreover, he believes that with new research and changing political interests, the status quo of permanent sameness of memory will change as well. ${ }^{48}$ Like Barnouw, Matthäus insists that the more people restrict their analysis of an incriminating act, the greater the risk of severing causal and chronological connections with other, less relevant (or less collective) aspects of the past. ${ }^{49}$ Through a comparative analysis of the political, social, cultural, and economic aspects of 'ordinary' Germans before, during, and after WWII and the Holocaust, this paper has created a dialogue between the works of Frank Bajohr, Dagmar Barnouw, Peter Fritzsche, Daniel Jonah Goldhagen, Marion A. Kaplan, Eric A. Johnson and Karl-Heinz Reuband, Thomas Kühne,

\footnotetext{
${ }^{46}$ Barnouw, The War in the Empty Air, 54.

${ }^{47}$ Ibid., 59.

${ }^{48}$ Ibid., 65.

${ }^{49}$ Matthäus, "Historiography and the Perpetrators of the Holocaust," 207.
} 
Jürgen Matthäus, and Detlev J.K. Peukert. Regardless of conflicting opinions, there can be little doubt, Matthäus reasons, that reconstructing the contextual framework of Holocaust perpetration is one of the greatest challenges for future historians. ${ }^{50}$ Therefore, the contextual framework of the Holocaust debate requires the integration of Intentionalist and Functionalist thought and the use of interdisciplinary approaches. Through the Synthesis Perspective, a better informed, more detailed and more nuanced picture of the interrelationship between German perpetrator and German survivor perspectives of the Holocaust can be formed. ${ }^{51}$

${ }^{50}$ Matthäus, "Historiography and the Perpetrators of the Holocaust," 211.

${ }^{51}$ Ibid., 208. 


\section{Bibliography}

Bajohr, Frank. "No "Volksgenossen": Jewish Entrepeneurs in the Third Reich." In Social Outsiders in Nazi Germany, edited by Robert Gellately and Nathan Stoltzfus, 45-65. New Jersey: Princeton University Press, 2001.

Barnouw, Dagmar. The War in the Empty Air. Bloomington: Indiana University Press, 2005.

Fritzsche, Peter. Life and Death in the Third Reich. Cambridge: Caravan Books, 2008.

Goldhagen, Daniel Jonah. Hitler's Willing Executioners. New York: Alfred A. Knope, Inc., 1996.

Johnson, Eric A., and Karl-Heinz Reuband. What We Knew: Terror, Mass Murder, and Everyday Life in Nazi Germany. Cambridge: Basic Books, 2005.

Kaplan, Marion A. "When the Ordinary Became Extraordinary: German Jews Reacting to Nazi Persecution, 1933-1939." In Social Outsiders in Nazi Germany, edited by Robert Gellately and Nathan Stoltzfus, 66-98. New Jersey: Princeton University Press, 2001.

Kühne, Thomas. Belonging and Genocide. New Haven: Yale University Press, 2010.

Matthäus, Jürgen. "Historiography and the Perpetrators of the Holocaust." In The Historiography of the Holocaust, edited by Dan Stone, 197-215. New York: Palgrave Macmillan, 2004.

Peukert, Detlev J.K. Inside Nazi Germany. Translated by Richard Deveson. London: Tameside Flimsetting Ltd, 1987. 